\title{
Isolation of Chicken Cellular DNA Sequences with Homology to the Region of Viral Oncogenes That Encodes the Tyrosine Kinase Domain
}

\author{
DAVID A. FOSTER, ${ }^{*}$ JOAN B. LEVY, GEORGE Q. DALEY, $†$ M. CELESTE SIMON, AND HIDESABURO \\ HANAFUSA
}

The Rockefeller University, New York, New York 10021

Received 25 July 1985/Accepted 4 October 1985

\begin{abstract}
A library of chicken genomic DNA was screened for sequences that could hybridize to a cloned DNA fragment containing the transforming gene (v-fps) of Fujinami sarcoma virus. In addition to c-fps, two unique chicken cellular DNA sequences were isolated that hybridized weakly to $\mathrm{v}$-fps. These sequences hybridized with many other viral oncogenes encoding tyrosine kinases. Sequence analysis of the region where homology was detected revealed a region that is highly conserved among the tyrosine kinases both at the nucleotide and amino acid levels. Although we were unable to detect expression of either chicken cellular DNA sequence in a variety of avian tissues, the data suggest the existence of additional members of the tyrosine kinase gene family. Screening genomic libraries for sequences that hybridize weakly to functional regions of other genes may prove useful for the isolation and characterization of additional members of other gene families.
\end{abstract}

Since the discovery that the src gene of Rous sarcoma virus encodes a gene product that possesses a protein kinase activity that is specific for tyrosine $(5,20)$, a number of other viral transforming genes have also been shown to encode tyrosine-specific protein kinases $(2,19)$. Sequence analysis has revealed a conserved domain in the region of these genes where the enzymatic activity has been mapped (19). These genes include $f p s$ of Fujinami sarcoma virus (37), yes of Y73 avian sarcoma virus (24), src of Rous sarcoma virus (36), ros of UR2 avian sarcoma virus (31), erb-B of avian erythroblastosis virus (49), $f g r$ of Gardner-Rasheed feline sarcoma virus (28), fms of Susan McDonough feline sarcoma virus (16), and $a b l$ of Abelson murine leukemia virus (34). Other viral oncogenes that do not possess a tyrosine-specific protein kinase activity also share amino acid homology with the tyrosine kinase genes. Among these are mos of Moloney murine sarcoma virus $(33,44)$, rel of reticuloendotheliosis virus (41), and mil of MH2 $(22,42)$. In addition to the viral oncogenes that have been characterized, other proteins have been isolated that possess tyrosine kinase activity. These include the growth factor receptors for epidermal growth factor $(4,9)$, for platelet-derived growth factor $(11,17)$, for insulin-like growth factor-1 (21), and for insulin $(10,18,23$, 43). TPK 75 is a tyrosine-specific protein kinase that was isolated from rat liver (48), and NCP94 is a tyrosine-specific protein kinase that was immunoprecipitated from bone marrow and other cells with an antibody raised against a peptide isolated from the tyrosine kinase domain of $f p s$ (13).

The ability to immunologically identify additional tyrosine specific protein kinases (13) suggests that tyrosine kinase genes could be detected by hybridization with DNA probes isolated from the conserved kinase region. Using this approach, we isolated two chicken cellular DNA sequences that likely represent additional members of the tyrosine kinase gene family.

Isolation of chicken cellular DNA sequences with homology

\footnotetext{
* Corresponding author.

† Present address: The Whitehead Institute for Biomedical Research, Cambridge, MA 02142.
}

to the tyrosine kinase domain of $f p s$. We previously described the cloning of c-fps from a chicken genome library (14a). Foster, M. Shibuya, and H. Hanafusa, Cell, in press). In addition to c- $f p s$, three other chicken cellular DNA clones were isolated by screening a chicken genomic library $(7,45)$ with a v-fps probe. The probe used was pBR-F04 (Fig. 1C) (38) which contains a portion of $v-f p s$ that shares homology with several viral tyrosine kinase genes (19). The level of hybridization between these clones and pBR-F04 was very weak relative to that observed between c-fps and pBR-F04, but still well above background at the moderately stringent conditions used (Fig. 1B). Using the Benton and Davis method for the screening of genomic libraries (1) allows hybridization to relatively high levels of cloned DNA. Thus, it is possible to isolate clones that hybridize weakly to the probe being used. The three chicken genomic clones that hybridized weakly with pBR-F04 ( $\lambda$ TKR24, $\lambda$ TKR11, and $\lambda$ TKR16) are shown in Fig. 2 . Two of them ( $\lambda$ TKR24 and $\lambda$ TKR11) appear to be overlapping based on restriction mapping and hybridization experiments. None of the three genomic clones hybridized with DNA from other regions of $\mathrm{v}-f p s$ (Fig. 1B).

Hybridization of cloned cellular sequences to other tyrosine kinase genes. Since pBR-F04 contains the region of $v-f p s$ that shares homology with other tyrosine kinases $(37,38)$, the possibility existed that these cellular DNA sequences (represented by $\lambda$ TKR24, -11 , and -16 ) would hybridize with other tyrosine kinases or tyrosine kinase-related genes. To test this possibility, plasmid DNAs containing cloned viral oncogene sequences with tyrosine kinase regions were hybridized with nick-translated DNA fragments isolated from $\lambda T K R 24$ and $\lambda$ TKR16. All plasmids were cut with restriction enzymes such that oncogene sequences were released from vector DNA sequences. The DNA fragments were separated by agarose gel electrophoresis, transferred to nitrocellulose, and hybridized with the labeled DNA fragments from $\lambda$ TKR24 and $\lambda$ TKR16. Table 1 summarizes the results of this analysis. DNA from both $\lambda$ TKR24 (representing $\lambda$ TKR11 as well) and $\lambda$ TKR16 hybridized weakly with several cloned DNAs coding for tyrosine kinases. Hence, these cellular 


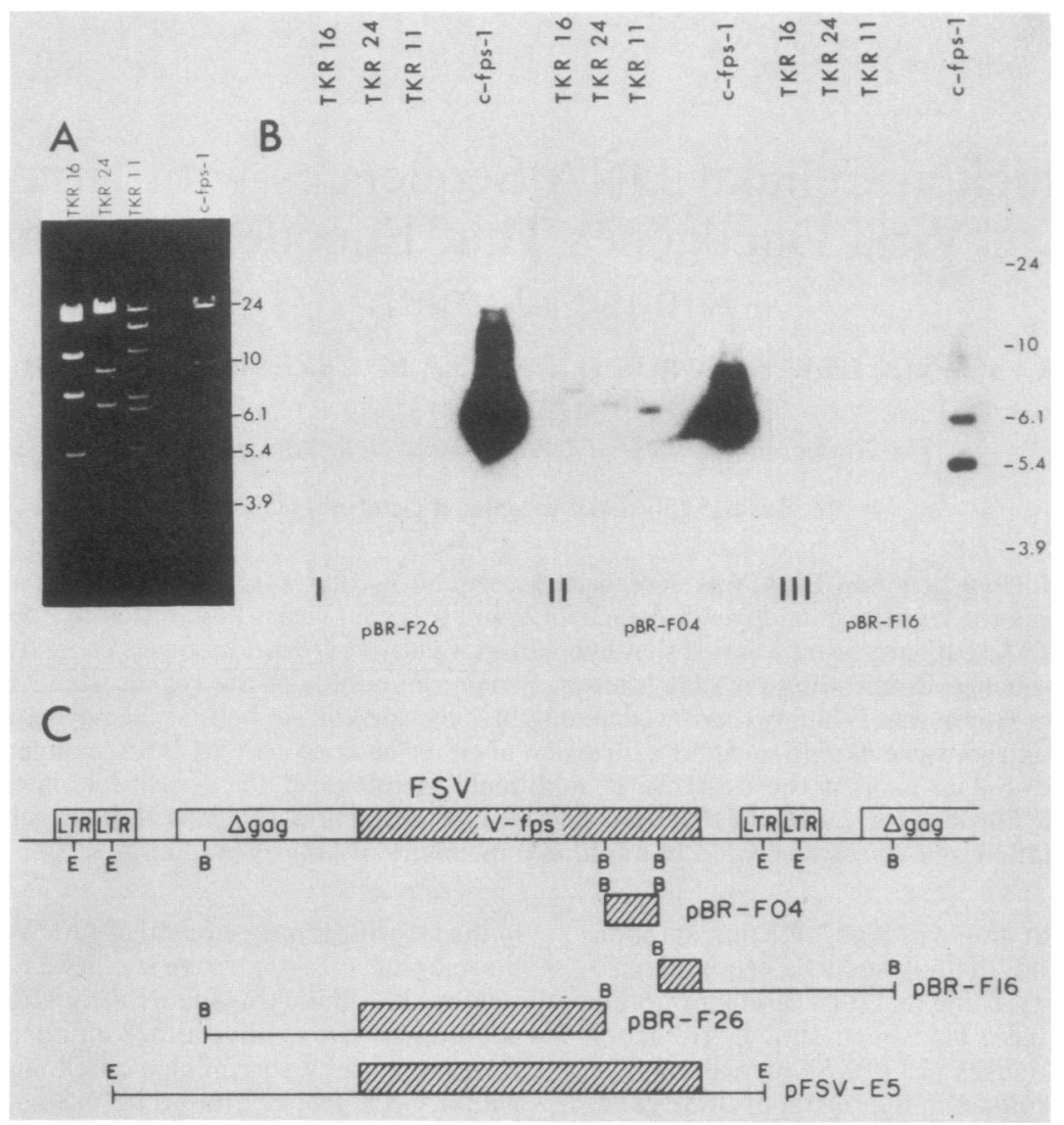

FIG. 1. Hybridization of v-fps DNA with chicken cellular DNA clones. The $\lambda$ DNA clones were digested with restriction enzymes and electrophoresed on a $0.8 \%$ agarose gel, transferred to nitrocellulose (40), and hybridized with v-fps probes under conditions of moderate stringency ( $3 \times \mathrm{SSC}$ [ $1 \times \mathrm{SSC}$ is $0.15 \mathrm{M} \mathrm{NaCl}$ plus $0.015 \mathrm{M}$ sodium citrate], $1 \times$ Denhardt, $50 \%$ formamide, $50 \mathrm{mM}$ Tris hydrochloride [pH 7.4], $0.02 \mathrm{mg}$ of yeast tRNA per $\mathrm{ml}, 0.02 \mathrm{mg}$ of sheared denatured salmon sperm DNA per ml, $1 \mathrm{mM} \mathrm{EDTA} ; 37^{\circ} \mathrm{C} ; 48 \mathrm{~h}$ ). The filters were washed two times for 30 min each in $0.1 \%$ sodium dodecyl sulfate- $0.1 \times \mathrm{SSC}$ at $50^{\circ} \mathrm{C}$. An ethidium-stained gel before transfer is shown in panel A. $\lambda$ TKR16 was digested with both $B a m H I$ and $X h o I$; $\lambda$ TKR24 was digested with $S s t \mathrm{I}$; $\lambda$ TKR11 was digested with $K p n I$; and $\lambda$ c-fps-1 (14a) was digested with $\mathrm{XhoI}$ (See Fig. 2 and Foster et al. [in press] for restriction maps of these sites). Autoradiographs are presented in panel B. In panel $C$ the Fujinama sarcoma virus (FSV) DNA sequences that were used as probes for the analysis of $\lambda$ DNA clones are shown. The cloning of pBR-F26, pBR-F04, pBR-F16, and pFSV-E5 was previously described (14a, 37). They contain 1.9, 0.4, 0.3, and 2.6 kilobases of $\mathrm{v}$-fps-specific sequence, respectively. pBR-F04 contains the portion of v-fps that shares homology with other tyrosine kinases (19, 31, 38). The shaded regions indicate v-fps-specific sequences. Abbreviations for restriction endonuclease sites are: B, BamHI; E, EcoRV. LTR, Long terminal repeat.
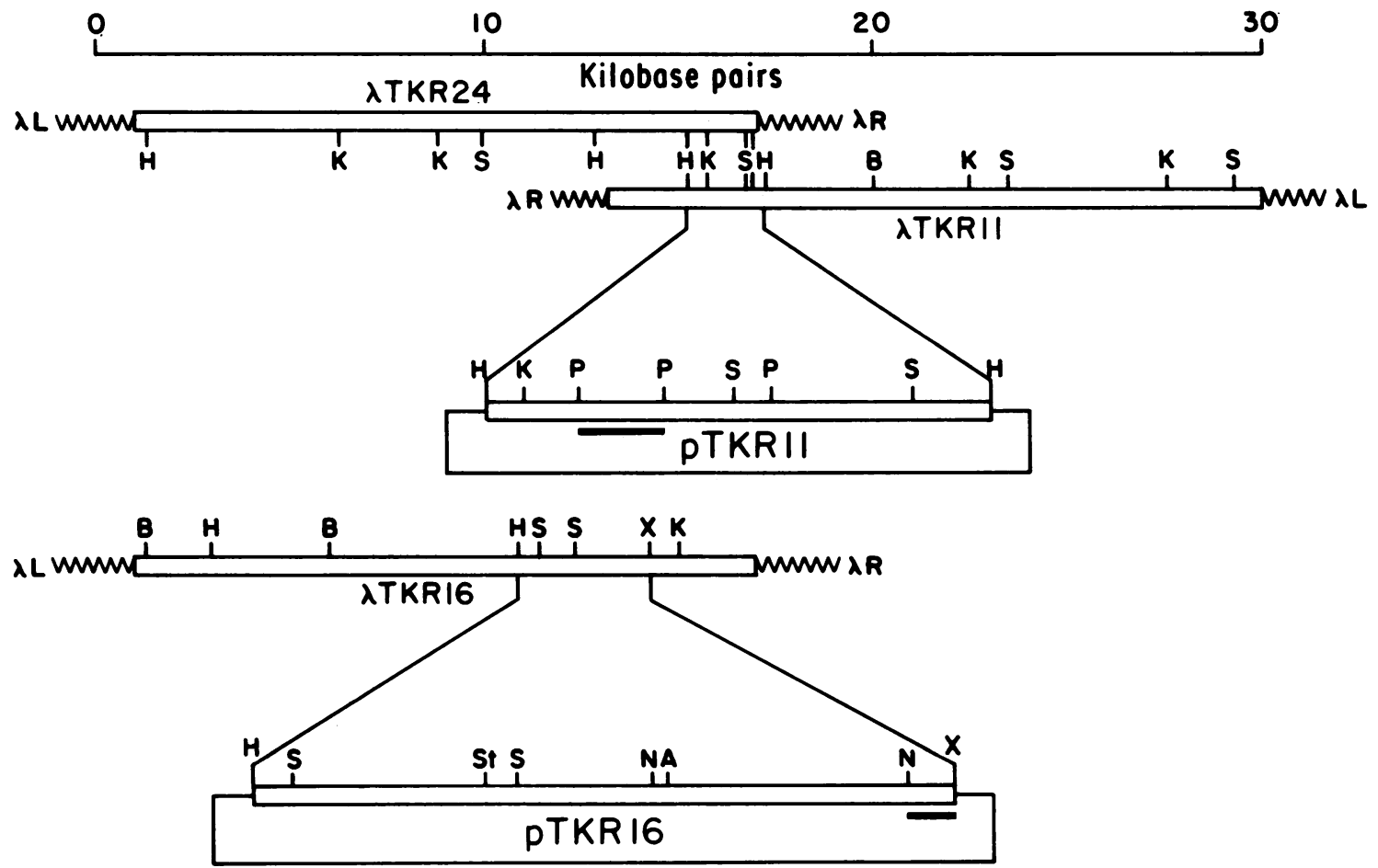
DNA sequences are designated TKR for tyrosine kinaserelated sequences. $\lambda$ TKR 24 and $\lambda$ TKR16 DNA sequences did not hybridize with nonconserved regions of tyrosine kinase genes (e.g., 5' or 3' fps, Fig. 1B; 5' v-fes or 3' v-erb-B, Table 1). In addition to the hybridization data presented in Table 1, weak hybridization was observed between $v-f p s$ and $\mathrm{v}$-yes, between v-src and v-yes, and between TKR24 and TKR16 under the same hybridization conditions (data not shown). The level of hybridization was comparable to that observed between $f p s$ and the two TKR clones. Hybridization has also been observed between v-fps and v-ros (30).

Sequence analysis of the TKR homology region. The region of homology to the v-fps gene within the TKR clones was further delimited by Southern blot analysis of restriction endonuclease-digested DNA from the subclones (pTKR11 and pTKR16) shown in Fig. 2. For pTKR11, the homology was contained between two PvuII sites as shown in Fig. 2, and for pTKR16, the homology was located between an NcoI site and the XhoI site (Fig. 2). Both of these restriction fragments were cloned into M13 (26) and sequenced by the procedure of Sanger et al. (35). The sequences obtained are shown in Fig. 3 and are compared with that of $v-f p s$ and the other avian tyrosine kinase genes. A highly conserved nucleotide sequence is seen between nucleotides 50 and 95 in Fig. 3. This region most likely accounts for the observed hybridization.

Using the DNA sequence from the strand that contained the homology to fps and the other tyrosine kinase genes, the amino acid sequences in three frames were examined. Open reading frames in both sequences were found that were homologous to other tyrosine kinase genes. In Fig. 4 the amino acid sequences of the two TKR sequences are compared with those of other genes known to encode a tyrosine kinase or have an amino acid sequence that is related to the tyrosine kinases. The very highly conserved regions are boxed. Both of the TKR clones contain open reading frames that are highly homologous to the boxed regions. The percentage of homology with the various genes compared in Fig. 4 is summarized in Table 2 .

The amino acid sequence of TKR16 sharply diverges upstream from amino acid 14 (Fig. 4) which corresponds to nucleotide 57 (Fig. 3). This could be explained by a potential splice acceptor site (27) at nucleotide 55 in the DNA sequence (Fig. 3). Similarly, the TKR11 sequence diverges downstream from about amino acid 60 (nucleotide 182). There are two potential splice donor sites (27) at nucleotides 185 and 211 before a TGA stop codon (Fig. 3). Both of the splice donor sites are upstream from a highly conserved region that is absent in pTKR11 (Fig. 4). These data suggest that the coding sequences of both TKR sequences are interrupted with introns.

Expression of TKR sequences. RNA was isolated from a
TABLE 1. Hybridization of TKR clones to other tyrosine kinase or tyrosine kinase-related viral oncogenes ${ }^{a}$

\begin{tabular}{|c|c|c|c|c|}
\hline \multirow{2}{*}{ Viral oncogene } & \multirow{2}{*}{ Clone } & \multirow{2}{*}{ Reference } & \multicolumn{2}{|c|}{$\begin{array}{l}\text { Relative hybrid- } \\
\text { ization to: }\end{array}$} \\
\hline & & & $\begin{array}{l}\text { TKR24/ } \\
\text { TKR11 }\end{array}$ & TKR16 \\
\hline \multicolumn{5}{|l|}{ Tyrosine kinases } \\
\hline fps & pBR-F04 & 38 & +++ & +++ \\
\hline fes $\left(5^{\prime}\right)$ & pPst3 & 12 & - & - \\
\hline fes $\left(3^{\prime}\right)$ & pPst4 & 12 & - & ++ \\
\hline$s r c$ & pSRA2 & 6 & ++ & ++ \\
\hline ros & pros & 30 & +++ & +++ \\
\hline yes & $\mathrm{pY} 73^{b}$ & & +++ & +++ \\
\hline$a b l$ & pAB3sub3 & 15 & ++ & + \\
\hline$f g r$ & pGRFeSV & 29 & - & + \\
\hline fms & pSM3 & 8 & ++ & + \\
\hline$e r b-B\left(3^{\prime}\right)$ & perb2 ${ }^{c}$ & & - & - \\
\hline$e r b-B\left(5^{\prime}\right)$ & perb5 ${ }^{c}$ & & ++ & $\mathrm{ND}^{d}$ \\
\hline \multicolumn{5}{|c|}{ Tyrosine kinase related } \\
\hline $\operatorname{mos}$ & pc-mos ${ }^{e}$ & & - & - \\
\hline rel & pEcoRel & 3 & - & - \\
\hline raf & pv-raf & 32 & + & + \\
\hline
\end{tabular}

${ }^{a}$ All clones containing the indicated viral oncogene sequences were digested wih restriction enzymes to liberate completely the oncogene sequences from pBR322 vector sequences. The digested DNA was then run on a $1 \%$ agarose gel transferred to nitrocellulose, and probed with nick-translated TKR DNA (isolated from $\lambda$ DNA clones to avoid contamination with pBR322). For the TKR24/TKR11 probe, the 7-kilobase SstI $\lambda$ TKR24 fragment that hybridized with pBR-F04 (Fig. 1B, panel II) was isolated, and for the TKR16 probe the 8-kilobase BamHI to XhoI fragment that hybridized with pBR-F04 was isolated from $\lambda$ TKR16. Hybridizations were carried out under the same moderately stringent conditions used in Fig. 1 . The relative hybridization was estimated based on the degree of hybridization of the TKR sequences with vfps (Fig. 1B, panel II, for a comparison of the hybridization of TKR sequences with $v-f p s$ and $c-f p s$ sequences with the $v-f p s)$. The level of hybridization of $v$ fps with the TKR sequences was given a value of +++ ; barely detectable hybridization of the TKR sequences was given a value of $+;$ and intermediate levels of hybridization were given a value of ++ . The values are not intended to be rigorously quantitative at this low level of hybridization but rather to point out reproducible differences in the pattern of hybridization of the two TKR sequences to the various tyrosine kinase or tyrosine kinase-related DNAs.

${ }^{b}$ pY73 was constructed by liberating Y73 sequences from a $\lambda$ DNA clone (24) with SstI, ligating, cutting with BamHI, and inserting into the BamHI site of $\mathrm{pBR} 322$.

c perb5 contains the region of $e r b-B$ that is homologous to the tyrosine kinases. It contains a BamHI containing this region cloned into this site in pBR322 $(46,49)$. perb2 is directly $3^{\prime}$ to this region and does not contain the region of $e r b-B$ that is homologous to other tyrosine kinases. It contains a downstream BamHI to EcoRI fragment $(46,49)$.

${ }^{d}$ ND, Not determined.

e pc-mos was obtained from G. Vande Woude. This clone has not been published. Oncogene sequences were liberated according to his instructions and restriction data. pc-mos was cut with $A v a I$ and HindIII.

FIG. 2. Isolation of chicken cellular DNA sequences homologous to v-fps. A chicken genomic library (45) was screened for sequences homologous to v-fps DNA (pBR-F04 was used as a probe; Fig. 1) by the technique of Benton and Davis (1). Five clones were isolated: two that hybridized strongly as previously reported for the c-fps gene (14a), and three that hybridized weakly. The conditions for hybridization are given in the legend to Fig. 1. The weakly homologous $\lambda$ DNA clones were grown up by standard techniques (25), and restriction enzyme cleavage sites were mapped. Hybridization with DNA representing the entire v-fps sequence (pFSV-E5 in Fig. 1) limited the region of homology to $v-f p s$ to the expanded portions of the $\lambda$ clones. These regions of the $\lambda$ DNA clones that hybridized with v-fps DNA were subcloned into pBR322. A HindIII fragment from $\lambda$ TKR11 containing the portion of the cloned DNA that hybridized with $f p s$ was cloned into the HindIII site of pBR322 to generate pTKR11. A HindIII to XhoI fragment from $\lambda$ TKR16 that hybridized with fps was cloned into pBR322 cut with HindIII and SalI to generate pTKR16 (SalI and XhoI have compatible sticky ends). The regions of pTKR11 and pTKR16 that hybridize with $f p s$ were further localized to the regions underlined with the heavy bars. Enzyme abbreviations are as follows: A, AvaI; B, BamHI; H, HindIII; K, KpnI; N, NcoI; P, PvuII; S, SstI; St, StuI; X, XhoI. L and R refer to the left and right arms of the $\lambda$ DNA clones, respectively. 


\begin{tabular}{|c|c|c|c|c|c|c|}
\hline $\begin{array}{l}\text { tkrll } \\
\text { tkrl6 } \\
\text { fps } \\
\text { ros } \\
\text { yes } \\
\text { src } \\
\text { erbB }\end{array}$ & $\begin{array}{r}10 \\
\text { CTGGTGGCAT } \\
\text {-AT-GACAGA } \\
\text { TGATCAAG-- } \\
\text { TCTTG-AT-- } \\
\text {-G-TG-A-- } \\
\text { TC-TC-AT-- } \\
\text { T-CTCAA-TG }\end{array}$ & $\begin{array}{r}20 \\
\text { GTTGCGTGGC } \\
\text {-C--T-ACAA } \\
\text {-A--GAGAAT } \\
\text { A-GCTTG-AT } \\
\text {-GCTGC-CAG } \\
\text {-GCTGC-CAG } \\
\text {--GTGTGCAG }\end{array}$ & $\begin{array}{r}30 \\
\text { ATTGCAGCAG } \\
\text { CAG-----GC } \\
\text { GCC--G--G- } \\
---T G C A A-- \\
-----T-A T- \\
-----T-C- \\
-----A A G-\end{array}$ & $\begin{array}{r}40 \\
\text { GCATGAACTA } \\
\text { TTGAAGTTGT } \\
---- \text { G-G-- } \\
- \text { TTGTGT-- } \\
----G C T- \\
- \text { A- }\end{array}$ & $\begin{array}{r}50 \\
\text { CCTGGCTGAT } \\
\text { TTACTTCTC- } \\
--- \text { AAAGC } \\
\text { TT-A-AGA-A } \\
\text {-A-T-AAAGA } \\
\text { TGT--AAAGA } \\
---- \text { AGG-A }\end{array}$ & $\begin{array}{r}60 \\
\text { ATGAACTACG } \\
\text { T--C-G-G-A } \\
-A-C---G-A \\
---C G T-T-A \\
------A \\
----A--- \\
\text { CGTCG-CT-G }\end{array}$ \\
\hline $\begin{array}{l}\text { tkrll } \\
\text { tkrl6 } \\
\text { fps } \\
\text { ros } \\
\text { yes } \\
\text { src } \\
\text { erbB }\end{array}$ & 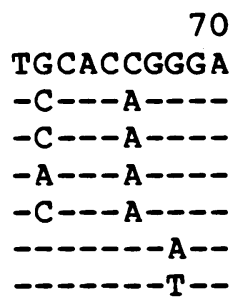 & $\begin{array}{r}80 \\
\text { CCTGGCTGCC } \\
------T \\
--------- \\
--------T \\
\text { T--CCGG } \\
---- \text { A } \\
---T-----\end{array}$ & 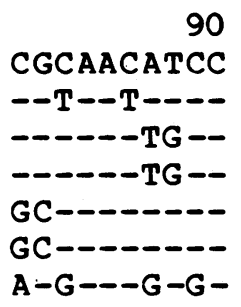 & $\begin{array}{r}100 \\
\text { TGGTCAACAG } \\
\text {-CT-GTCAGA } \\
----G-C A G A \\
-\mathrm{T}-- \text { GTCTGA } \\
-\mathrm{T}-- \text { AGGAGA } \\
---- \text {-GGGGGA } \\
-\mathrm{T}-\mathrm{T}-\mathrm{T}-\mathrm{C}-\mathrm{C}\end{array}$ & $\begin{array}{r}110 \\
\text { CAACCTGGTC } \\
--- \text { TAAC--G } \\
\text { A--GAACAC- } \\
\text { G--G-AATAT } \\
---T--T--G \\
\text { G-- } \\
\text { TCCA-AACAT }\end{array}$ & $\begin{array}{r}120 \\
\text { TGCAAGGTCT } \\
\text { GT---AA--- } \\
\text { CTG--AA--A } \\
\text { G-G-GCTG-- } \\
--\mathrm{T}--\mathrm{AA}-\mathrm{AG} \\
------\mathrm{GG} \\
\text { GTG--AA--A }\end{array}$ \\
\hline $\begin{array}{l}\text { tkrll } \\
\text { tkrl6 } \\
\text { fps } \\
\text { ros } \\
\text { yes } \\
\text { src } \\
\text { erbB }\end{array}$ & $\begin{array}{r}130 \\
\text { CCGACTTCGG } \\
\text { GT--T--T-- } \\
\text { GC----T- } \\
-- \text { CGAG-G-T } \\
-\mathrm{A}- \\
-\mathrm{T}- \\
-\mathrm{A}-\mathrm{-}-\mathrm{-}\end{array}$ & $\begin{array}{l}140 \\
\text { CCTCTCCCGT } \\
\text {-T-GG-T--A } \\
\text { GGATGT-GCG } \\
\text { AAAGATTG-- } \\
\text { T---G-AA-G } \\
\text { G--GG-A--C } \\
\text { G--GG-AAAG }\end{array}$ & $\begin{array}{r}150 \\
\text { TTCCTGGAGG } \\
\\
\text { GCAGGA-GA- } \\
\text { GATT-T-GAC } \\
\text { C-AA-A-- } \\
\text { C--A-C-- } \\
\text { C-G-T-T- }\end{array}$ & $\begin{array}{r}160 \\
\text { ATGACACCTC } \\
\\
\text { GATGGTGTCT } \\
\text { T--C--GAGA } \\
\text {-CA-T-GATA } \\
\text {-CA--GAG-A } \\
\text { CA--TGAGAA }\end{array}$ & $\begin{array}{r}170 \\
\text { TGATCCCACT } \\
\\
\text { ATGC-T-CAC } \\
\text {-ATCTAT-AA } \\
\text { CAC-G-G-GG } \\
\text { CACAG-ACGG } \\
\text { G--GTATCAC }\end{array}$ & $\begin{array}{l}\text { GGGGGGCAT- } \\
\text { AATGATTA-T } \\
\text { C-AGGAGCTA } \\
\text { C-AGGTGC-A } \\
\text { GCAGAGG-A- }\end{array}$ \\
\hline $\begin{array}{l}\text { tkrll } \\
\text { fps } \\
\text { ros } \\
\text { yes } \\
\text { src } \\
\text { erbB }\end{array}$ & $\begin{array}{r}190 \\
\text { CACTGGTAAA } \\
\text { A-GCA-ATCC } \\
\text { A-AGGAA--G } \\
\text { A-T-TCC--T } \\
\text { AGT-CCCC-T } \\
\text { GCAA---TCC }\end{array}$ & $\begin{array}{l}200 \\
\text { GCTGCTTTTC } \\
\text { C-GTGAAA-G } \\
\text { AGGAGAAGG- } \\
\text { TAAATGGACT } \\
\text { CAA-TGGACA } \\
\text { TA-TAAA-GG }\end{array}$ & $\begin{array}{r}210 \\
\text { GACAGCAGGA } \\
---T-- \text { CCCC } \\
\text { CTACT-CCTG } \\
\text {-CTCCAGAAG } \\
\text {-C-CC-GA-G } \\
\text { ATGGCATT-G }\end{array}$ & $\begin{array}{r}220 \\
\text { GTGATGGGTG } \\
\text {-A-GCTCTGA } \\
\text { TCAGAT--AT } \\
\text { CA-CATT--A } \\
\text { CA-CCCTC-A } \\
\text { AGTCAATTTT }\end{array}$ & $\begin{array}{r}230 \\
\text { GGGAGGAAAG } \\
\text { ATT-C-GCT- } \\
-- \text { CTCCTG-A } \\
\text { T--TC-GTTT } \\
\text { T--CC-GTTC } \\
\text { ACACC---TT }\end{array}$ & $\begin{array}{r}240 \\
\text { GAGAGTGAGG } \\
\text {-TACAGCTC- } \\
\text { AGCCTCATT- } \\
\text { ACA-TCA-T } \\
\text { ACC-TCA-T } \\
\text { T-T-C-C-TC }\end{array}$ \\
\hline tkrll & $\begin{array}{r}250 \\
\text { GAGAAGTCTC }\end{array}$ & $\begin{array}{r}260 \\
\text { CTGTTGATGT }\end{array}$ & $\begin{array}{r}270 \\
\text { TAAGAATGCT }\end{array}$ & $\begin{array}{r}280 \\
\text { TTTCTCAAGT }\end{array}$ & $\begin{array}{r}290 \\
\text { GCCAACAATG }\end{array}$ & $\begin{array}{r}300 \\
\text { GAATAATGTG }\end{array}$ \\
\hline & $\begin{array}{r}310 \\
\text { CCAAGTGGAA }\end{array}$ & $\begin{array}{r}320 \\
\text { GTATCAATCA }\end{array}$ & $\begin{array}{r}330 \\
\text { CATGAATGAA }\end{array}$ & $\begin{array}{r}340 \\
\text { GAAGGTCTT }\end{array}$ & $\begin{array}{r}350 \\
\text { TCTTGCAAC }\end{array}$ & $\begin{array}{r}360 \\
\text { TTTGTGCCCA }\end{array}$ \\
\hline
\end{tabular}

$\operatorname{tkr} 11$

370

FIG. 3. Nucleic acid sequence of TKR11 and TKR16 and comparison with the sequence of other avian tyrosine kinases in the conserved region. The regions of pTKR11 and pTKR16 that hybridized with fps DNA (Fig. 2) were sequenced as described in the text. The homologous regions of the two sequences are shown here and compared with the corresponding sequences of $f p s(37)$, ros $(31)$, yes $(24)$, src (36), and erb-B (49). The sequences were aligned according to the amino acid homologies shown in Fig. 4 and those reported previously $(19,31)$. Where the nucleotides are identical, a dash is substituted for the nucleotide. A potential splice acceptor site for TKR16 is underlined at nucleotide 55, and two potential splice donor sites for TKR11 are underlined at nucleotides 186 and 211.

variety of chicken tissues by the methods described by Maniatis et al. (25). This poly(A)-selected RNA was subjected to agarose gel electrophoresis, transferred to nitrocellulose, and hybridized with radioactively labeled TKR DNA as described previously (47). pTKR11 and pTKR16 (Fig. 2) were used as probes to test for the expression of the TKR sequences. We were unable to detect significant levels of expression of either TKR sequence in any of several tissues examined (leg muscle, intestine, lung, spleen, liver, kidney, bone marrow, and brain). The lack of expression in liver and bone marrow suggests that the sequences reported here do not represent the tyrosine kinases recently characterized from these tissues by immunological and biochemical techniques $(13,48)$.
Conservation of TKR sequences. Chromosomal DNA isolated from several sources was digested with HindIII, run on an agarose gel, transferred to nitrocellulose (40), and probed with pTKR11 and pTKR16. Hybridizing fragments of different sizes were found in all of the avian and mammalian DNAs examined (Fig. 5). In the mammalian DNAs, it appeared that both TKR sequences hybridized to the same band. Thus, both TKR sequences are apparently fairly well conserved among the avian species and possibly in mammals as well. Upon long exposure (Fig. 5A), lower-level hybridization to several other bands could be detected in all of the DNAs, suggesting that there are other TKR sequences in addition to those reported here.

It is possible that the TKR sequences represent highly 


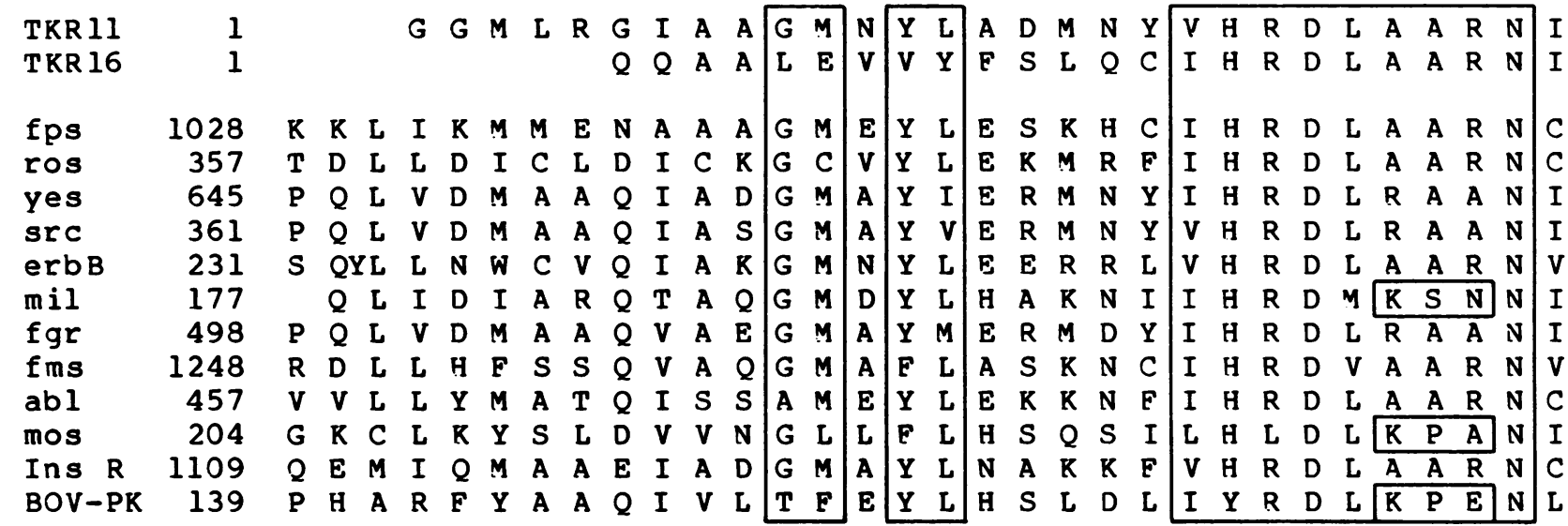

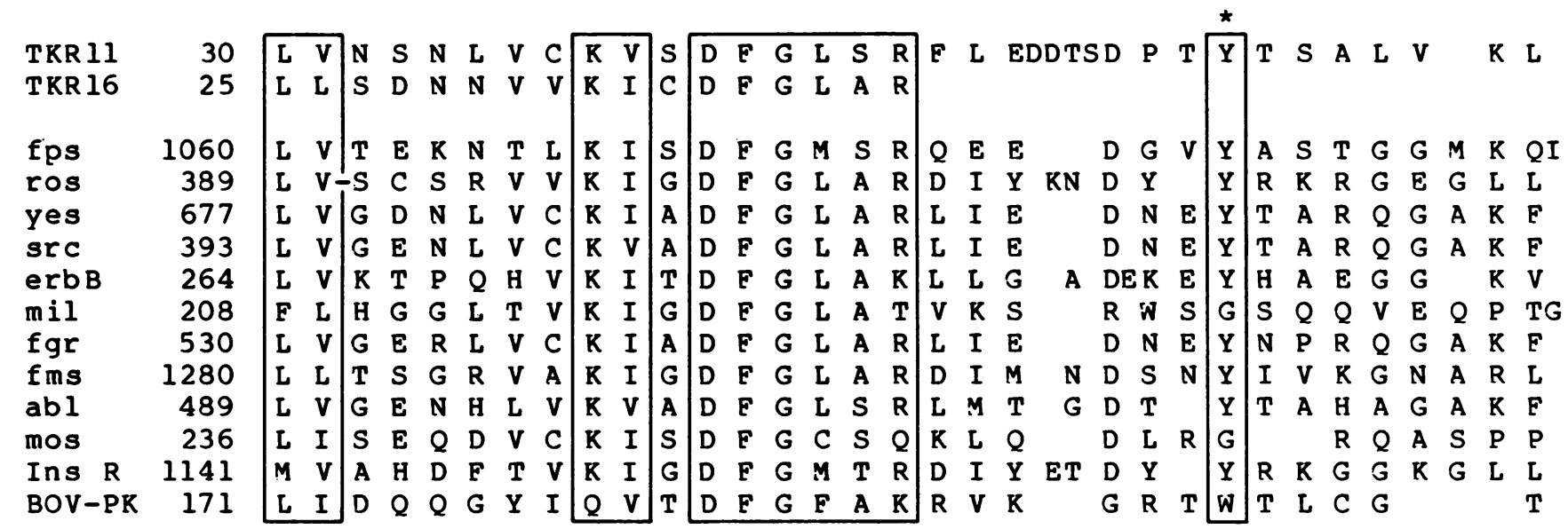

$\begin{array}{lllllllllllllllllllllll}\text { TKR I1 } & 62 & \text { L } & \text { F } & D & S & R & S & D & G & W & G & G & K & E & S & E & G & E & V & S & C & 0\end{array}$

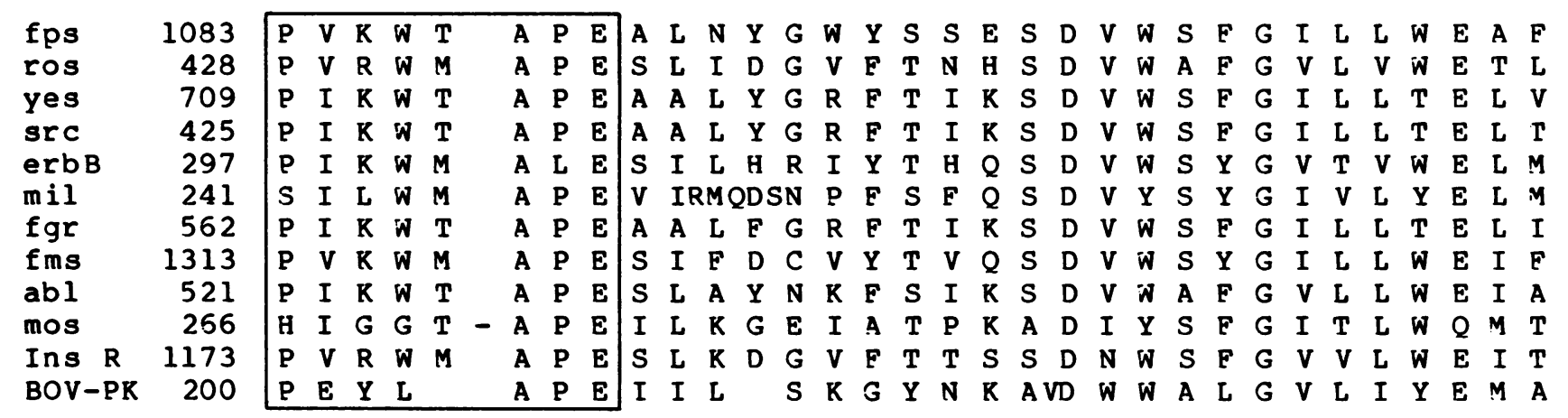

FIG. 4. Amino acid sequence of TKR11 and TKR16 and comparison with the sequence of other tyrosine kinases in the conserved region. The amino acid sequences of TKR11 and TKR16 were determined from the sequence data presented in Fig. 3. The sequences have been aligned to give the maximum homology with other genes sharing homology in this region as previously described $(19,31)$. The sequences used for comparison are as follows: the $f p s$ gene of Fujinami sarcoma virus (37), the ros gene of UR2 avian sarcoma virus (31), the yes gene of Y73 avian sarcoma virus (24), the src gene of the Pr-C strain of Rous sarcoma virus (36), the erb-B gene of avian erythroblastosis virus (49), the mil gene of MH2 avian carcinoma virus $(22,42)$, the $\mathrm{fgr}$ gene of Gardner-Rasheed feline sarcoma virus (28), the fms gene of Susan McDonough feline sarcoma virus (16), the $a b l$ gene of Abelson murine leukemia virus (34), the mos gene of Moloney murine leukemia virus (33, 44), the insulin receptor (Ins R) $(10,43)$, and the bovine cyclic AMP-dependent protein kinase (Bov-PK) (39). Boxes have been drawn around the highly conserved regions. The asterisk indicates the major site of tyrosine phosphorylation for several of the viral oncogenes. The dash in the ros sequence represents an insert of the amino acids SEKQYG at position 391 (31). The dash in the mos sequence represents an insert of the sequence YTHQ at position 270 (44). 
TABLE 2. Comparison of the homology of TKR sequences with other related genes at the amino acid level ${ }^{a}$

\begin{tabular}{lcc}
\hline \multirow{2}{*}{ Gene } & \multicolumn{2}{c}{ \% Homology with: } \\
\cline { 2 - 3 } & TKR11 & TKR16 \\
\hline fps & 50 & 63 \\
ros & 44 & 78 \\
yes & 60 & 74 \\
src & 62 & 63 \\
erb-B & 43 & 63 \\
mil & 37 & 56 \\
fgr & 54 & 67 \\
fms & 45 & 70 \\
abl & 49 & 67 \\
mos & 33 & 44 \\
Ins R & 43 & 48 \\
Bov-PK & 23 & 37 \\
\hline
\end{tabular}

${ }^{a}$ The amino acid sequences of TKR11 and TKR16 were compared with the amino acid sequences of the other related gene sequences shown in Fig. 4 through the region of homology, and the percentage of homology was determined. In the case of TKR11, the region of comparison includes amino acids 1 to 52; for TKR16 it includes amino acids 15 to 41 .

diverged pseudogenes. However, the homology with many tyrosine kinase genes (Table 1), the apparent presence of introns (Figs. 3 and 4), and the extent of conservation of these sequences in other species (Fig. 5) makes this possibility unlikely. It is also unlikely that these sequences encode a previously identified tyrosine kinase since the TKR sequences do not show particularly strong homology with any of the known tyrosine kinases (Fig. 4; Tables 1 and 2). It is likely that the unique genomic sequences reported here represent additional tyrosine kinases that differ from those already reported. We cannot be sure that these sequences encode tyrosine-specific protein kinases since they also

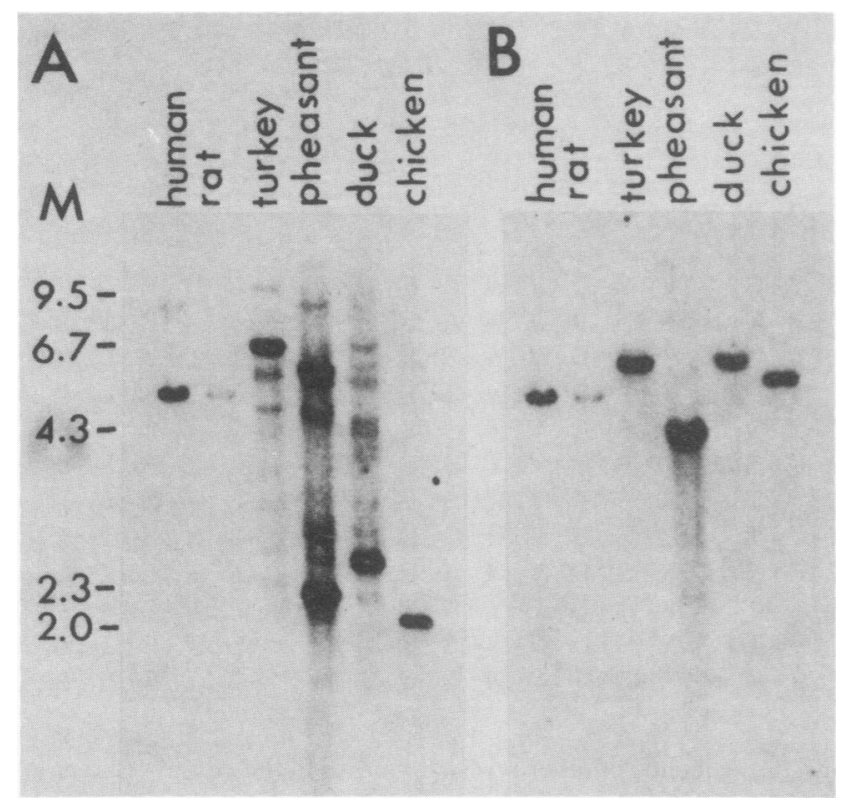

FIG. 5. Conservation of the TKR sequences among other species. Chromosomal DNA was isolated from a variety of avian and mammalian sources. The DNAs were digested with HindIII, subjected to agarose gel electrophoresis, transferred to nitrocellulose and probed with pTKR11 (A) or pTKR16 (B) as described previously (14). The DNAs were isolated from the livers of Peking ducks, ring-necked pheasants, and turkeys and from chicken embryo fibroblasts, HeLa cells (human), and Rat-1 cells. Lane M, HindIIIcut $\lambda$ DNA markers. share homology with genes that do not encode a tyrosine kinase. Of particular interest in this regard are the highly conserved amino acids LAARN (beginning with amino acid 24 for TKR11 in Fig. 4). All of the tyrosine kinases contain either this sequence or the closely related sequence LRAAN. All the related proteins that phosphorylate serine or threonine rather than tyrosine (mos, mil, Bov-PK) are different in this region (Fig. 4). Whether this difference is important for the specificity of protein kinases for substrate is not known. However, both of the TKR clones have a sequence common to the tyrosine kinases.

We thank J. B. Dodgson, B. Vennstrom, and S. Hughes for chicken genomic libraries and L.-H. Wang for assistance in the RNA studies. We thank the following people for providing oncogene plasmid clones: C. J. Sherr for pPst3, pPst4, pSM3; L.-H. Wang for pros; J. M. Bishop for pSRA2; S. Goff for pAB3sub3; K. Robbins for pGRFeSV; J. Samarut for perb2 and perb5; G. Vande Woude for pc-mos; H. Temin for pEcoRel; U. Rapp for pv-raf. $\lambda$-Y73-11a was obtained from M. Yoshida. We thank B. Mathey-Prevot for Rat-1 cells and J. Nevins for HeLa cells. G. Peter Wehrle is ackowledged for his criticism. Thanks are extended to R. Jove, A. Dutta, and L.-H. Wang for comments on the manuscript.

This work was supported by Public Health Service grant CA14935 from the National Cancer Institute. D.A.F. is a recipient of a National Research Service Award (F32-CA07141) from the National Cancer Institute. J.B.L. was supported by a National Research Service Award training grant (F32-A107233).

\section{LITERATURE CITED}

1. Benton, W. D., and R. W. Davis. 1977. Screening $\lambda$-gt recombinant clones by hybridization to single plaques in situ. Science 196:180-182.

2. Bishop, J. M., and $H$. Varmus. 1982. Transforming genes, $p$ 999-1108. In R. Weiss, N. Teich, H. Varmus, and J. Coffin (ed.), RNA tumor viruses. Cold Spring Harbor Laboratory, Cold Spring Harbor, N.Y.

3. Chen, I. S. Y., T. W. Mak, J. J. O'Rear, and H. Temin. 1981. Characterization of reticuloendotheliosis virus strain T DNA and isolation of a novel variant of reticuloendotheliosis virus strain T by molecular cloning. J. Virol. 40:800-811.

4. Cohen, S., H. Ushiro, C. Stoscheck, and M. Chinkers. 1982. A native 170,000 epidermal growth factor receptor-kinase complex from shed plasma membrane vesicles. J. Biol. Chem. 257: 1523-1531.

5. Collett, M. S., and R. L. Erikson. 1978. Protein kinase activity associated with the avian sarcoma virus src gene product. Proc. Natl. Acad. Sci. USA 75:2021-2024.

6. DeLorbe, W. J., P. A. Luciw, H. M. Goodman, H. E. Varmus, and J. M. Bishop. 1980. Molecular cloning and characterization of avian sarcoma virus circular DNA molecules. J. Virol. 36:50-61.

7. Dodgson, J. B., J. Strommer, and J. D. Engel. 1979. Isolation of the chicken beta-globin gene and a linked embryonic beta-like globin gene from a chicken DNA recombinant library. Cell 17:879-887.

8. Donner, L., L. A. Fedele, C. F. Garon, S. J. Anderson, and C. J. Sherr. 1982. McDonough feline sarcoma virus: characterization of the molecularly cloned provirus and its feline oncogene (v-fms). J. Virol. 41:489-500.

9. Downward, J., Y. Yarden, E. Mayes, G. Scrace, N. Totty, P. Stockwell, A. Ulrich, J. Schlessinger, and M. Waterfield. 1984. Close similarity of epidermal growth factor receptor and v-erb-B oncogene protein sequences. Nature (London) 307:521-527.

10. Ebina, Y., L. Ellis, K. Jarnagin, M. Edery, L. Graf, E. Clauser, J. Ou, F. Masiarz, Y. W. Kan, I. D. Goldfine, R. A. Roth, and W. J. Rutter. 1985. The human insulin receptor cDNA: the structural basis for hormone activated transmembrane signalling. Cell 40:747-758.

11. Ek, B., B. Westermark, A. Wasteson, and C.-H. Heldin. 1982. Stimulation of tyrosine-specific phosphorylation by plateletderived growth factor. Nature (London) 295:419-420. 
12. Fedele, L. A., J. Even, C. F. Garon, L. Donner, and C. J. Sherr. 1981. Recombinant bacteriophages containing the integrated transforming provirus of Gardner-Arnstein feline sarcoma virus. Proc. Natl. Acad. Sci. USA 78:4036-4040.

13. Feldman, R. A., J. L. Gabrilove, J. P. Tam, M. A. S. Moore, and H. Hanafusa. 1985. Specific expression of the human cellular fps/fes-encoded protein NCP92 in normal and leukemic myeloid cells. Proc. Natl. Acad. Sci. USA 82:2379-2383.

14. Foster, D. A., and H. Hanafusa. 1983. A fps gene without gag gene sequences transforms cells in culture and induces tumors in chickens. J. Virol. 48:744-751.

14a.Foster, D. A., M. Shibuyu, and H. Hanafusa. 1985. Activation of the transformation potential of the cellular fps gene. Cell 42:105-115.

15. Goff, S. P., E. Gilboa, O. N. Witte, and D. Baltimore. 1980. Structure of the Abelson murine leukemia virus genome and the homologous cellular gene: studies with cloned viral DNA. Cell 22:757-766.

16. Hampe, A., M. Gobet, C. J. Sherr, and F. Galibert. 1984 Nucleotide sequence of the feline retroviral oncogene $v$-fms shows unexpected homology with oncogenes encoding tyrosinespecific protein kinases. Proc. Natl. Acad. Sci. USA 81:85-89.

17. Heldin, C.-H., B. Ek, and L. Ronnstrand. 1983. Characterization of the receptor for platelet-derived growth factor on human fibroblasts. Demonstration of an intimate relationship with a 185,000 dalton substrate for the platelet-derived growth factorstimulated kinase. J. Biol. Chem. 258:10054-10061.

18. Heldin, C.-H., and B. Westermark. 1984. Growth factors: mechanism of action and relation to oncogenes. Cell 37:9-20.

19. Hunter, T. 1984. The proteins of oncogenes. Sci. Am. 251:70-79.

20. Hunter, T., and B. M. Sefton. 1980. Transforming gene product of Rous sarcoma virus phosphorylates tyrosine. Proc. Natl. Acad. Sci. USA 77:1311-1315.

21. Jacobs, S., F. C. Kull, Jr., H. S. Earp, M. E. Svoboda, J. J. Van Wyk, and P. Cuatrecasas. 1983. Somatomedin-C stimulates the phosphorylation of the $\beta$ subunit of its own receptor. J. Biol. Chem. 258:9581-9584.

22. Kan, N. C., C. S. Flordellis, G. E. Mark, P. H. Deusberg, and T. S. Papas. 1984. Nucleotide sequence of avian carcinoma virus MH2: two potential onc genes, one related to avian virus MC29 and the other to murine sarcoma virus 3611. Proc. Natl. Acad. Sci. USA 81:3000-3001.

23. Kasuga, M., Y. Zick, D. L. Blithe, F. A. Karlsson, H. U. Haring, and C. R. Kahn. 1982. Insulin stimulation of phosphorylation of the $\beta$-subunit of the insulin receptor. Formation of both phosphoserine and phosphotyrosine. J. Biol. Chem. 257: 9891-9894.

24. Kitamura, N., A. Kitamura, K. Toyoshima, Y. Hirayama, and M. Yoshida. 1982. Avian sarcoma virus Y73 genome sequence and structural similarity of its transforming gene product to that of Rous sarcoma virus. Nature (London) 297:205-208

25. Maniatis, T., E. F. Fritsch, and J. Sambrook. 1982. Molecular cloning, a laboratory manual. Cold Spring Harbor Laboratory, Cold Spring Harbor, N.Y.

26. Messing, J., and J. Vieira. 1982. A new pair of M13 vectors for selecting either DNA strand of double-digested restriction fragments. Gene 19:269-276.

27. Mount, S. M. 1982. A catalogue of splice junction sequences. Nucleic Acids Res. 10:459-472.

28. Naharro, G., K. C. Robbins, and E. P. Reddy. 1981. Gene product of $v$-fgr onc: hybrid protein containing a portion of actin and a tyrosine-specific protein kinase. Science 223:63-66.

29. Naharro, G., S. R. Trinick, S. Rasheed, M. B. Gardner, S. A. Aaronson, and K. C. Robbins. 1983. Molecular cloning of integrated Gardner-Rasheed feline sarcoma virus: genetic structure of its cell-derived sequence differs from that of other tyrosine kinase-coding onc genes. J. Virol. 47:611-619.

30. Neckameyer, W. S., and L.-H. Wang. 1984. Molecular cloning and characterization of avian sarcoma virus UR2 and comparison of its transforming sequence with those of other avian sarcoma viruses. J. Virol. 50:914-921.
31. Neckameyer, W. S., and L.-H. Wang. 1985. Nucleotide sequence of avian sarcoma virus UR2 and comparison of its transforming gene with other members of the tyrosine protein kinase oncogene family. J. Virol. 53:879-884.

32. Rapp, U. R., M. D. Goldsborough, G. E. Mark, T. I. Bonner, J. Groffen, F. H. Reynolds, and J. R. Stephenson. 1983. Structure and biological activity of v-raf, a unique oncogene transduced by a retrovirus. Proc. Natl. Acad. Sci. USA 80:4218-4222.

33. Reddy, E. P., M. J. Smith, E. Canaani, K. C. Robbins, S. R. Tronick, S. Zain, and S. A. Aaronson. 1980. Nucleotide sequence analysis of the transforming region and large terminal redundancies of Moloney murine sarcoma virus. Proc. Natl. Acad. Sci. USA 77:5234-5238.

34. Reddy, E. P., M. J. Smith, and A. Srinivasan. 1983. Nucleotide sequence of Abelson murine leukemia virus genome: structural similarity of its transforming gene product to other onc gene products with tyrosine-specific protein kinase activity. Proc. Natl. Acad. Sci. USA 80:3623-3627.

35. Sanger, F., S. Nicklen, and A. R. Coulson. 1977. DNA sequencing with chain terminating inhibitors. Proc. Natl. Acad. Sci. USA 74:5463-5467.

36. Schwartz, D. E., R. Tizard, and W. Gilbert. 1983. Nucleotide sequence of Rous sarcoma virus. Cell 32:853-869.

37. Shibuya, M., and H. Hanafusa. 1982. Nucleotide sequence of Fujinami sarcoma virus: evolutionary relationship of its transforming gene with transforming genes of other sarcoma viruses. Cell 30:787-795.

38. Shibuya, M., L.-H. Wang, and H. Hanafusa. 1982. Molecular cloning of the Fujinami sarcoma virus genome and its comparison with sequences of other related transforming viruses. J. Virol. 42:1007-1016.

39. Shoji, S., D. Parmelee, R. Wade, S. Kumar, L. Ericsson, K. Walsh, H. Neurath, G. Long, J. Demaille, E. Fisher, and K. Titani. 1981. Complete amino acid sequence of the catalytic subunit of the bovine cardiac muscle cyclic AMP-dependent protein kinase. Proc. Natl. Acad. Sci. USA 78:848-851.

40. Southern, E. M. 1975. Detection of specific sequences among DNA fragments separated by gel electrophoresis. J. Mol. Biol. 98:503-517.

41. Stephans, R. M., N. R. Rice, R. R. Hiebsch, H. R. Bose, Jr., and R. V. Gilden. 1983. Nucleotide sequence of $v$-rel, the oncogene of reticuloendotheliosis virus. Proc. Natl. Acad. Sci. USA 80:6229-6233.

42. Sutrave, P., T. I. Bonner, U. R. Rapp, H. W. Jansen, T. Patschinsky, and K. Bister. 1984. Nucleotide sequence of avian retroviral oncogene $v$-mil: homologue of murine retroviral oncogene $v$-raf. Nature (London) 309:85-88.

43. Ulrich, A., J. R. Bell, E. Y. Chen, R. Herrera, L. M. Petruzzelli, T. J. Dull, A. Gray, L. Coussens, Y.-C. Liao, M. Tsubokawa, A. Mason, P. H. Seeberg, C. Grunfeld, O. M. Rosen, and J. Ramachandran. 1985. Human insulin receptor and its relationship to the tyrosine kinase family of oncogenes. Nature (London) 313:756-761.

44. Van Beveren, C., J. A. Gallenshaw, V. Jonas, A. J. M. Berns, R. F. Doolittle, D. J. Donoghue, and I. M. Verma. 1981. Nucleotide sequence and formation of the transforming gene of a mouse sarcoma virus. Nature (London) 289:258-262.

45. Vennstrom, B., and J. M. Bishop. 1982. Isolation and characterization of chicken DNA homologous to the two putative oncogenes of avian erythroblastosis virus. Cell 28:135-143.

46. Vennstrom, B., L. Fanshier, C. Moscovici, and J. M. Bishop. 1980. Molecular cloning of the avian erythroblastosis virus genome and recovery of oncogenic virus by transfection of chicken cells. J. Virol. 36:575-585.

47. Wang, L.-H., P. Snyder, T. Hanafusa, and H. Hanafusa. 1980. Evidence for the common origin of viral and cellular sequences involved in sarcomagenic transformation. J. Virol. 35:52-64.

48. Wong, T. W., and A. R. Goldberg. 1983. Tyrosyl protein kinases in normal rat liver: identification and partial characterization. Proc. Natl. Acad. Sci. USA 80:2529-2533.

49. Yamamoto, T., T. Nishida, N. Miyajima, S. Kawai, T. Ooi, and K. Toyoshima. 1983. The erbB gene of avian erythroblastosis virus is a member of the $s r c$ gene family. Cell 35:71-78. 